\title{
Pengaruh Kombinasi Ekstrak Etanol Kulit Buah Delima (Punica granatum L.) dengan Batang Sereh (Cymbopogon citratus) Terhadap Bakteri Escherichia coli ATCC 8739
}

\section{The Effect of Combination of Ethanol Extract of (Punica granatum) L. and (Cymbopogon citratus) Against Escherichia coli ATCC 8739}

\author{
Suci Ahda Novitri ${ }^{*}$, Neng Fisheri Kurniati ${ }^{2}$ \\ ${ }^{1}$ Program Studi Farmasi, Fakultas Ilmu Kesehatan, Universitas Islam Negeri Syarif \\ Hidayatullah Jakarta \\ ${ }^{2}$ Sekolah Farmasi, Institut Teknologi Bandung \\ *Email: suci.ahda@uinjkt.ac.id
}

\begin{abstract}
ABSTRAK
Escherichia coli merupakan salah satu bakteri yang banyak ditemukan dimasyarakat sebagai penyebab penyakit infeksi. Beberapa strain bakteri ini terbukti mengalami resisten terhadap antibiotik. Tujuan dari penelitian ini adalah untuk mengetahui aktivitas antibakteri ekstrak etanol kulit buah delima dan batang sereh terhadap bakteri Escherichia coli ATCC 8739 serta pengaruhnya jika dikombinasikan. Aktivitas antibakteri ekstrak tanaman uji dengan metode mikrodilusi dan difusi agar dilakukan untuk mengetahui nilai konsentrasi hambat minimum (KHM) dan konsentrasi bunuh minimum (KBM). Kemudian dilakukan pengujian kombinasi tanaman uji dengan metode difusi pita kertas. Hasil penelitian ini menunjukkan bahwa ekstrak etanol kulit buah delima dan batang sereh memiliki aktivitas antibakteri terhadap bakteri Escherichia coli ATCC 8739. Nilai KHM ekstrak etanol kulit buah delima terhadap bakteri uji lebih rendah dibanding dengan ekstrak etanol batang sereh. Kombinasi ekstrak etanol kulit buah delima dan batang sereh terhadap bakteri Escherichia coli ATCC 8739 menunjukkan efek yang aditif. Kesimpulan dari penelitian ini adalah kombinasi ekstrak etanol kulit buah delima dan ekstrak etanol batang sereh terhadap bakteri Escherichia coli ATCC 8739 dapat memberikan efek aditif.
\end{abstract}

Kata kunci : antibakteri, KHM, KBM, kulit buah delima, batang sereh, Escherichia coli

\section{ABSTRACT}

Escherichia coli is a bacteria that is commonly found in the community as a cause of infectious diseases. Several strains of these bacteria have been shown to be resistant to antibiotics. The purpose of this study was to determine the antibacterial activity of the ethanol extract of pomegranate peel and lemongrass against Escherichia coli ATCC 8739 and its effects when combined. The antibacterial activity of the test plant extract was determined by microdilution and agar diffusion method to obtain the value of the minimum inhibitory concentration (MIC) and the minimum bactericidal concentration $(M B C)$. Then the test plant combination was tested using diffusion method by the paper strip. The results of this study showed that the ethanol extract of pomegranate peel and lemongrass had antibacterial activity against Escherichia coli ATCC 8739. The MIC value of the ethanol extract of pomegranate peel against the tested bacteria was lower than the ethanol extract of lemongrass. The combination of the ethanol extract of pomegranate peel and lemongrass against Escherichia coli ATCC 8739 showed an additive effect. The conclusion of this study is the combination of pomegranate peel ethanol extract and lemongrass ethanol extract against the Escherichia coli ATCC 8739 bacteria showed an additive effect.

Keywords : antibacteria, MIC, MBC, pomegranate peel, lemongrass, Escherichia coli 


\section{PENDAHULUAN}

Resistensi antimikroba menurut laporan World Health Organization (WHO) tahun 2014 merupakan masalah kesehatan masyarakat yang semakin serius mencapai tingkat yang mengkhawatirkan. Adanya bakteri yang mengalami multidrug-resistant akan menyebabkan pengobatan antimikroba menjadi tidak efektif, memperpanjang durasi penyakit dan rawat inap, dan meningkatkan kematian (WHO, 2014). Bakteri yang resisten terhadap antibiotik juga disebabkan karena penggunaan antibiotik yang semakin meluas. Dengan meluasnya bakteri yang resisten terhadap antibiotik, maka dibutuhkan pengembangan dan penggalian sumber obat-obatan antimikroba lain seperti tanaman obat bahan alam.

Bahan alam digunakan pada penelitian ini adalah kulit buah delima (Punica granatum L.) dan batang sereh (Cymbopogon citratus) dan sebagai antibakteri. Kulit buah delima mengandung alkaloid pelletierin, granatin, asam betulik, asam ursolik, isokuersertin, elagitanin, triterpenoid, kalsium oksalat dan pati (Dalimartha, 2008). Elagitanin adalah kandungan yang diduga memiliki aktivitas antibakteri (Machado et al., 2002). Pada penelitian sebelumnya, ekstrak metanol kulit buah delima telah terbukti memiliki aktivitas terhadap bakteri Escherichia coli, Staphylococcus aureus dan Pseudomonas aeruginosa (Duman et al., 2009). Sedangkan Cymbopogon citratus mengandung senyawa yang terdiri dari citral, sitronelol, geranial, neral, mirsen, golongan terpena, sinamaldehida, linalool, sitral, sitronelal, eugenol, dan fenol yang bersifat sebagai antibakteri (Rahman, 2013) (Koffi et al., 2009) (Knobloch et al., 1989).

Pada penelitian ini, akan diuji aktivitas antibakteri ekstrak etanol kulit buah delima dan batang sereh terhadap bakteri Escherichia coli ATCC 8739 serta pengaruhnya jika dikombinasikan.

\section{BAHAN DAN METODE}

Bahan

Bahan yang digunakan pada penelitian ini adalah batang sereh, ekstrak etanol kulit buah delima, dimetilsufoksida (DMSO), alkohol 70\%, air suling, media Muller-Hinton Agar (MHA), media
Muller-Hinton Broth (MHB), tetrasiklin, kapas berlemak, kertas saring, bakteri uji. Bakteri yang digunakan adalah bakteri Escherichia coli ATCC 8739.

Batang sereh diperoleh dari Lembang, Jawa Barat. Sereh segar dibersihkan dari pengotornya dengan cara dicuci dengan air hingga bersih, ditiriskan, dan dikeringkan dan dibuat menjadi serbuk simplisia. Ekstrak etanol dibuat dengan mencampurkan 400 gram simplisia dengan 2,5 L etanol $96 \%$ kemudian dimaserasi. Ekstraksi dilakukan tiga kali. Ekstrak etanol yang diperoleh disaring lalu dipekatkan dengan rotavapor, kemudian ekstrak dipanaskan lagi diatas penangas air dengan suhu $60^{\circ} \mathrm{C}$ hingga mengental (Departemen Kesehatan RI, 2000). Ekstrak etanol kulit buah delima, didapatkan dari penelitian sebelumnya (Azreen, 2015)

\section{Pengujian Aktivitas Antibakteri}

Setelah mendapatkan ekstrak etanol kulit buah delima dan ekstrak etanol batang sereh, maka uji aktivitas antibakteri kedua ekstrak serta kombinasinya terhadap bakteri Escherichia coli ATCC 8739 dilakukan. Media Muller-Hinton Agar (MHA) dibuat dengan cara: sebanyak 35 gram serbuk media Muller-Hinton Agar (MHA) dilarutkan dalam 1 liter akuades, dilakukan pemanasan sambil diaduk. Larutan ditempatkan pada labu erlenmeyer, ditutup dengan kassa steril kemudian disterilisasi dengan autoklaf pada suhu $121^{\circ} \mathrm{C}$ selama 15 menit. Media Muller-Hinton Broth (MHB) dibuat dengan cara: sebanyak 21 gram serbuk media Muller-Hinton Broth (MHB) dilarutkan dalam 1 liter akuades, dilakukan pemanasan sambil diaduk. Larutan ditempatkan pada labu erlenmeyer, ditutup dengan kasa steril kemudian disterilisasi dengan autoklaf pada suhu $121^{\circ} \mathrm{C}$ selama 15 menit.

Bakteri Escherichia coli ATCC 8739 diinokulasikan terlebih dahulu pada agar miring MHA dengan cara digoreskan rapat secara zigzag dari bawah ke atas menggunakan jarum ose bundar dan diinkubasi pada inkubator selama 24 jam pada suhu $37^{\circ} \mathrm{C}$. Bakteri yang telah diinkubasi dan tumbuh pada agar miring diambil dengan jarum ose bundar dan disuspensikan pada $5 \mathrm{~mL}$ media MHB, lalu diinkubasi selama 24 jam pada suhu $37^{\circ} \mathrm{C}$. Hari berikutnya, suspensi bakteri uji diencerkan dengan MHB hingga menghasilkan 
absorban $\quad 0,08 \quad-\quad 0,13 \quad$ menggunakan spektrofotometri UV-Vis pada panjang gelombang $625 \mathrm{~nm}$ (setara dengan 0,5 McFarland). Setelah dihasilkan absorbansi pada rentang tersebut, suspensi bakteri diencerkan lagi dengan MHB sehingga diperoleh jumlah akhir bakteri yang terkandung pada tiap satu sumur pelat setara dengan kira-kira $5 \times 10^{5} \mathrm{CFU} / \mathrm{mL}$ (rentang 2-8 $\times 10^{5} \mathrm{CFU} / \mathrm{mL}$ ).

Pada pengujian mikrodilusi, ekstrak uji ditimbang sebanyak $0,164 \mathrm{~g}$ dan dilarutkan dalam $1 \mathrm{~mL}$ DMSO 100\%. Kemudian, sebanyak 0,1 mL dari larutan tersebut diambil dan ditambahkan 0,9 mL MHB. Sedangkan untuk tetrasiklin ditimbang sebanyak 10,24 mg dan dilarutkan dalam $1 \mathrm{~mL}$ DMSO $100 \%$. Kemudian, sebanyak $0,1 \mathrm{~mL}$ dari larutan tersebut diambil dan ditambahkan $0,9 \mathrm{~mL}$ MHB.

Pengujian aktivitas antibakteri dengan metode mikrodilusi dilakukan untuk menentukan nilai Konsentrasi Hambat Minimum (KHM) dan Konsentrasi Bakterisid Minimum (KBM). Pengujian dilakukan dengan menggunakan microwell plate yang terdiri dari 8 baris dan 12 kolom sehingga total terdapat 96 sumur pelat mikro. Pada setiap pengujian, diikutsertakan kontrol negatif pada sumur pertama dan kontrol pertumbuhan pada sumur kedua. Kontrol negatif hanya berisi media MHB saja, sedangkan kontrol pertumbuhan berisi media MHB dan suspensi bakteri uji. Langkah pertama adalah semua sumur diisi dengan media MHB sebanyak $100 \mu \mathrm{L}$, kecuali kontrol negatif yang berisi $200 \mu \mathrm{L}$ media MHB. Setelah itu, ke dalam kolom kedua belas yang telah berisi $100 \mu \mathrm{L}$ media MHB ditambahkan ekstrak atau pembanding tetrasiklin sebanyak $100 \mu \mathrm{L}$. Dari kolom kedua belas ini, diambil $100 \mu \mathrm{L}$ campuran kemudian dipindahkan ke dalam kolom kesebelas. Pengenceran terus dilakukan hingga kolom ketiga yang akan memiliki konsentrasi ekstrak atau pembanding terkecil. Setelah itu, suspensi bakteri uji yang sudah diencerkan dimasukkan ke dalam semua sumur kecuali pada kolom kontrol negatif yang berada pada kolom pertama. Microwell plate diinkubasi selama 18-24 jam pada suhu $35 \pm 2{ }^{\circ} \mathrm{C}$. Konsentrasi Hambat Minimum (KHM) diamati sebagai konsentrasi paling rendah dimana tidak terdapat endapan bakteri pada dasar sumur (jernih) yang mengindikasikan terhambatnya pertumbuhan bakteri. Pengujian ini dilakukan secara triplo.

Nilai KBM ditentukan dengan cara dipipet sebanyak $5 \mu \mathrm{L}$ larutan sumur plat mikro dari hasil uji mikrodilusi yang menunjukkan daerah jernih (tidak ada kekeruhan atau endapan bakteri di dasar sumur) dan pada konsentrasi di atas daerah jernih. Selanjutnya larutan ini digoreskan pada media MHA yang telah padat di cawan petri dan diinkubasi selama 24 jam pada suhu $37^{\circ} \mathrm{C}$. KBM diperoleh jika tidak ada pertumbuhan bakteri di permukaan media agar.

Penentuan diameter hambat dilakukan dengan cara: kultur murni bakteri uji disuspensikan dalam MHB dan diinkubasikan selama 18-24 jam pada suhu $37^{\circ} \mathrm{C}$. Suspensi bakteri yang sudah diinkubasikan ini kemudian diencerkan dengan menggunakan MHB, suspensi bakteri inilah yang akan digunakan dalam percobaan. Kemudian $50 \mu \mathrm{L}$ suspensi bakteri tersebut ditambahkan dengan $15 \mathrm{~mL}$ MHA steril yang belum memadat, hasil campuran ini kemudian di-vortex hingga homogen. Campuran ini kemudian dituangkan ke dalam cawan petri steril dan dibiarkan memadat. Kemudian cakram kertas (ukuran diamater cakram sebesar $5 \mathrm{~mm}$ ) dicelupkan ke dalam ekstrak etanol kulit buah delima dengan konsentrasi 2xKHM, 4xKHM dan 8xKHM. Cakram kertas hasil celupan tadi dikeringkan lalu diletakkan di atas MHA yang telah mengandung bakteri uji. Hal yang sama dilakukan terhadap ekstrak etanol batang sereh dan tetrasiklin. Selain itu, cakram juga dicelupkan ke dalam campuran MHB dan DMSO 10\% sebagai kontrol negatif yang terbukti tidak memiliki hambatan. Kemudian cawan petri diinkubasi pada suhu $37^{\circ} \mathrm{C}$ selama $18-24$ jam. Setelah diinkubasi, daerah bening di sekitar cakram kertas diukur menggunakan jangka sorong untuk menentukan diameter hambat terhadap bakteri uji.

Penentuan efek kombinasi ekstrak dengan metode difusi agar menggunakan pita kertas (Lorian and Fodor, 1974). Kultur murni bakteri uji disuspensikan dalam MHB dan diinkubasikan selama 18-24 jam pada suhu $37^{\circ} \mathrm{C}$. Suspensi bakteri yang sudah diinkubasikan ini kemudian diencerkan dengan menggunakan MHB, suspensi bakteri inilah yang akan digunakan dalam percobaan. Kemudian $50 \mu \mathrm{L}$ suspensi bakteri 
tersebut ditambahkan dengan $15 \mathrm{~mL}$ MHA steril yang belum memadat, hasil campuran ini kemudian di-vortex hingga homogen. Campuran ini kemudian dituangkan ke dalam cawan petri steril dan dibiarkan memadat. Satu buah pita dicelupkan dalam larutan ekstrak etanol kulit buah delima dan satu pita lagi dicelupkan kedalam larutan ekstrak etanol batang sereh. Pita kertas yang telah kering ini lalu diletakkan di atas MHA yang telah mengandung bakteri uji dengan pertemuan pita kertas ini membentuk sudut $90^{\circ}$. Cawan petri diinkubasikan pada suhu $37^{\circ} \mathrm{C}$ selama 18-24 jam. Hambatan di pertemuan kedua pita kertas tersebut diamati.

\section{HASIL}

Berdasarkan tabel 1., nilai KHM ekstrak etanol kulit buah delima terhadap bakteri
Escherichia coli ATCC 8739 adalah sebesar 256 $\mu \mathrm{g} / \mathrm{mL}$ dengan KBM sebesar > $4096 \mu \mathrm{g} / \mathrm{mL}$. Sedangkan nilai KHM ekstrak etanol batang sereh terhadap bakteri Escherichia coli ATCC 8739 adalah sebesar $4096 \mu \mathrm{g} / \mathrm{mL}$ dengan KBM sebesar $>4096 \mu \mathrm{g} / \mathrm{mL}$. Nilai KHM tetrasiklin terhadap bakteri Escherichia coli ATCC 8739 adalah sebesar $1 \mu \mathrm{g} / \mathrm{mL}$ dengan KBM sebesar $32 \mu \mathrm{g} / \mathrm{mL}$. Berdasarkan tabel 1., nilai KHM ekstrak etanol kulit buah delima terhadap bakteri Escherichia coli ATCC 8739 adalah sebesar 256 $\mu \mathrm{g} / \mathrm{mL}$ dengan KBM sebesar > $4096 \mu \mathrm{g} / \mathrm{mL}$. Sedangkan nilai KHM ekstrak etanol batang sereh terhadap bakteri Escherichia coli ATCC 8739 adalah sebesar $4096 \mu \mathrm{g} / \mathrm{mL}$ dengan KBM sebesar $>4096 \mu \mathrm{g} / \mathrm{mL}$.

Tabel 1. Nilai KHM dan KBM Ekstrak Etanol Tanaman Uji terhadap Bakteri Escherichia coli ATCC 8739

\begin{tabular}{lcccc}
\hline & KHM dan & \multicolumn{3}{c}{ Nilai KHM dan KBM $(\mu \mathrm{g} / \mathrm{mL})$} \\
\cline { 3 - 5 } & $\mathrm{KBM}(\mu \mathrm{g} / \mathrm{mL})$ & Punica granatum & $\begin{array}{c}\text { Cymbopogon } \\
\text { citratus }\end{array}$ & Tetrasiklin \\
\hline Escherichia coli & $\mathrm{KHM}$ & 256 & 4096 & 1 \\
ATCC 8739 & $\mathrm{KBM}$ & $>4096$ & $>4096$ & 32 \\
\hline
\end{tabular}

Tabel 2. Diameter hambat Ekstrak Tanaman Uji terhadap Bakteri Escherichia coli ATCC 8739

\begin{tabular}{lcccc}
\hline & & \multicolumn{3}{c}{ Diameter hambat ekstrak tanaman uji (mm) } \\
\cline { 3 - 5 } \multicolumn{1}{c}{ Bakteri uji } & Konsentrasi & $\begin{array}{c}\text { Ekstrak etanol kulit } \\
\text { buah delima }\end{array}$ & $\begin{array}{c}\text { Ekstrak etanol } \\
\text { batang sereh }\end{array}$ & Tetrasiklin \\
\hline Escherichia coli & $2 \mathrm{KHM}$ & $6,70 \pm 0,58$ & $8,70 \pm 0,58$ & $7,0 \pm 0,00$ \\
ATCC 8739 & $4 \mathrm{KHM}$ & $10,0 \pm 1,00$ & $10,0 \pm 1,00$ & $8,7 \pm 0,58$ \\
& $8 \mathrm{KHM}$ & $13,3 \pm 0,58$ & $11,7 \pm 1,53$ & $10,3 \pm 0,58$ \\
\hline & & & & \\
& & & & \\
& & & & \\
& & & & \\
& & & &
\end{tabular}

Gambar 1. Kombinasi ekstrak etanol kulit buah delima (a) dan batang sereh (b) terhadap bakteri Escherichia coli ATCC 8739 
Diameter hambat ekstrak etanol kulit buah delima dan ektrak etanol batang sereh terhadap bakteri Escherichia coli ATCC 8739 dilakukan dengan menggunakan konsentrasi 2 KHM, 4 KHM dan 8 KHM. Berdasarkan tabel 2., diameter hambat ekstrak etanol kulit buah delima terhadap bakteri Escherichia coli ATCC 8739 pada konsentrasi 2 KHM, 4 KHM dan 8 KHM adalah sebesar $6,70 \pm 0,58,10,0 \pm 1,00$ dan $13,3 \pm 0,58 \mathrm{~mm}$ secara berurutan. Sedangkan diameter hambat ekstrak etanol batang sereh terhadap bakteri Escherichia coli ATCC 8739 pada konsentrasi 2 KHM, 4 KHM dan 8 KHM adalah sebesar $8,70 \pm 0,58$, $10,0 \pm 1,00$, dan $11,7 \pm 1,53 \mathrm{~mm}$ secara berurutan. Diameter hambat tetrasiklin terhadap bakteri Escherichia coli ATCC 8739 pada konsentrasi 2 KHM, 4 KHM dan 8 KHM adalah sebesar 7,0 $\pm 0,00$, $8,7 \pm 0,58$ dan $10,3 \pm 0,58 \mathrm{~mm}$.

\section{PEMBAHASAN}

Sebelum dilakukan uji aktivitas antibakteri kombinasi ekstrak etanol kulit buah delima dan batang sereh terhadap bakteri uji, maka dilakukan uji aktivitas antibakteri masing-masing ekstrak terhadap bakteri uji dengan menggunakan metode mikrodilusi. Hasil penelitian yang diperoleh menunjukkan bahwa ekstrak etanol kulit buah delima memiliki aktivitas antibakteri terhadap bakteri Escherichia coli ATCC 8739 dengan KHM sebesar $256 \mu \mathrm{g} / \mathrm{mL}$ dan KBM sebesar > 4096 $\mu \mathrm{g} / \mathrm{mL}$. Sedangkan ekstrak etanol batang sereh memiliki aktivitas antibakteri terhadap bakteri Escherichia coli ATCC 8739 dengan KHM sebesar $4096 \mu \mathrm{g} / \mathrm{mL}$ dan KBM sebesar > $4096 \mu \mathrm{g} / \mathrm{mL}$ (Tabel 1.). Dari hasil pengujian KHM dengan menggunakan metode mikrodilusi, ekstrak etanol kulit buah delima memiliki efek hambatan yang lebih baik terhadap bakteri Escherichia coli ATCC 8739 dibandingkan dengan ekstrak etanol batang sereh. Metode mikrodilusi ini memiliki kelebihan yaitu menggunakan sampel yang sedikit, biaya rendah, reproduktifitas (Benkova, Soukup and Marek, 2020), kuantitatif (Chen et al., 2020) dan mudah digunakan (Langfield et al., 2004).

Setelah nilai KHM setiap ekstrak diperoleh, selanjutnya dilakukan penentuan diameter hambat ekstrak etanol kulit buah delima dan batang sereh terhadap bakteri Escherichia coli ATCC 8739. Kontrol negatif yang digunakan adalah campuran media MHB dan DMSO $10 \%$ yang terbukti tidak memberikan diameter hambat. Penentuan diameter hambat ini bertujuan untuk melihat kepekaan aktivitas antimikroba dari ekstrak etanol kulit buah delima dan batang sereh terhadap bakteri Escherichia coli ATCC 8739 dengan metode difusi agar menggunakan cakram kertas yang berdiameter $5 \mathrm{~mm}$. Kelebihan dari metode difusi agar yaitu metodenya sederhana, reproduktifitas, mudah dalam modifikasi, biaya rendah. Metode ini perlu memperhatikan difusibilitas senyawa yang digunakan (Benkova, Soukup and Marek, 2020). Pada penelitian ini, diduga kebanyakan senyawa yang terkandung didalam ekstrak etanol batang sereh merupakan senyawa yang bersifat nonpolar (seperti: minyak atsiri) (Matasyoh et al., 2011). Sedangkan media agar yang digunakan oleh senyawa tersebut untuk berdifusi bersifat polar sehingga senyawa-senyawa yang bersifat nonpolar tersebut akan kesulitan untuk berdifusi. Oleh karena itu, diperoleh hasil penelitian diameter hambat ekstrak etanol kulit buah delima dan batang sereh terhadap bakteri Escherichia coli ATCC 8739 yang dapat dilihat pada Tabel 2.

Setelah didapatkan hasil KHM tiap esktrak tanaman uji terhadap bakteri, maka dilakukan pengujian efek kombinasi ekstrak etanol kulit buah delima dengan ekstrak etanol batang sereh terhadap bakteri Escherichia coli ATCC 8739 dengan menggunakan konsentrasi masingmasing 8 KHM dengan metode difusi pita 
DOI: http://dx.doi.org/10.30633/jkms.v12i1.893

kertas. Hasil pengujian kombinasi ekstrak etanol kulit buah delima dengan ekstrak etanol batang sereh menunjukkan efek aditif terhadap bakteri Escherichia coli ATCC 8739 yang dibuktikan dengan tidak adanya pertambahan luas hambatan pada pertemuan hambatan antara ekstrak etanol kulit buah delima dan ekstrak etanol batang sereh (gambar 1.).

\section{KESIMPULAN}

Ekstrak etanol kulit buah delima menunjukkan aktivitas antibakteri terhadap bakteri Escherichia coli ATCC 8739 yang lebih baik dibandingkan dengan ekstrak etanol batang sereh. Pengaruh kombinasi ekstrak etanol kulit buah delima dan batang sereh terhadap bakteri Escherichia coli ATCC 8739 menunjukkan efek yang aditif.

\section{DAFTAR PUSTAKA}

Azreen, N. B. A. (2015) Antibacterial Activities of Peels of Punica granatum L., Rhizomes of Zingeber officinale L., and Leaves of Elephantopus scaber L. and Its Combination with Tetracycline Hydrochloride Against Gram-Negative and Gram-Positive Bacteria, Skripsi. Institut Teknologi Bandung.

Benkova, M., Soukup, O. and Marek, J. (2020) 'Antimicrobial susceptibility testing: currently used methods and devices and the near future in clinical practice', Journal of Applied Microbiology, 129(4), pp. 806-822. doi: 10.1111/jam.14704.

Chen, S. C. et al. (2020) 'Comparison of microdilution method with agar dilution method for antibiotic susceptibility test of Neisseria gonorrhoeae', Infection and Drug Resistance, 13, pp. 1775-1780. doi: 10.2147/IDR.S253811.
CLSI (2012) Methods for Dilution Antimicrobial Susceptibility Tests for Bacteria That Grow Aerobically; Approved Standard - Ninth Edition. USA: Clinical and Laboratory Standards Institute.

Dalimartha, S. (2008) Atlas Tumbuhan Obat Indonesia Jilid 4. Jakarta: Pustaka Bunda.

Departemen Kesehatan RI, D. K. R. (2000) Parameter Standarisasi Umum Ekstrak Tumbuhan Obat. Jakarta: Direktorat Jenderal Pengawasan Obat dan Makanan.

Duman, A. D. et al. (2009) 'Antimicrobial activity of six pomegranate (Punica granatum L.) varieties and their relation to some of their pomological and phytonutrient characteristics', Molecules, 14(5), pp. 1808-1817. doi: 10.3390/molecules14051808.

Knobloch, K. et al. (1989) 'Antibacterial and antifungal properties of essential oil components', Journal of Essential Oil Research, 1(3), pp. 119-128. doi: 10.1080/10412905.1989.9697767.

Koffi, K. et al. (2009) 'In vitro cytotoxic activity of Cymbopogon citratus L. and Cymbopogon nardus L. essential oils from Togo', Bangladesh Journal of Pharmacology, 4(1), pp. 29-34. doi: 10.3329/bjp.v4i1.1040.

Langfield, R. D. et al. (2004) 'Use of a modified microplate bioassay method to investigate antibacterial activity in the Peruvian medicinal plant Peperomia galioides', Journal of Ethnopharmacology, 94(2-3), pp. 279281. doi: 10.1016/j.jep.2004.06.013.

Lorian, V. and Fodor, G. (1974) 'Technique for determining the bactericidal effect of drug combinations.', Antimicrobial agents and chemotherapy, 5(6), pp. 630-633. doi: 
10.1128/AAC.5.6.630.

Machado, T. D. B. et al. (2002) 'Antimicrobial ellagitannin of Punica granatum fruits', Journal of the Brazilian Chemical Society, 13(5), pp. 606-610. doi: 10.1590/S0103-50532002000500010.

Matasyoh, J. C. et al. (2011) 'Chemical composition of Cymbopogon citratus essential oil and its effect on mycotoxigenic Aspergillus species', African Journal of Food Science, 5(3), pp. 138-142. Available at: http://www.academicjournals.org/ajfs.

Rahman, H. (2013) Bioaktifitas Minyak Atsiri Sereh (Cymbopogon citratus DC.) Terhadap Pertumbuhan Bakteri Escherichia coli dan Staphylococcus aureus. Universitas HAsanudin.

WHO, W. H. O. (2014) Antimicrobial Resistance: Global Report on Surveillance, Wordl Health Organization. doi: 10.1016/j.giec.2020.06.004. 